УДК 7.06

\title{
Decoration of Children's Literature of the Indigenous Peoples of the North, Siberia and the Far East
}

\author{
Mariia A. Kolesnik* \\ Siberian Federal University \\ 79 Svobodny, Krasnoyarsk, 660041, Russia
}

Received 24.04.2016, received in revised form 18.06.2016, accepted 19.08.2016

The article discusses the basic principles of decoration of children's literature of the Indigenous Peoples of the North, Siberia and the Far East that are used by the artists-illustrators. The author carries out an analysis of several illustrations of some fairy tales of the peoples of the North, an analysis of decoration of fairy tale collections in order to determine which image of a certain ethnic group they form. The article briefly describes the work of such masters of children's illustration as E.K. Evenbakh, N.G. Basmanova, G.D. Pavlishin and E.M. Rachev.

Keywords: children's literature, Dolgans, art of illustration, art of the peoples of the North, book graphics, indigenous peoples, fairy tales of the peoples of the North, Nanai, Nenets, E.K. Evenbakh, G.D. Pavlishin, E.M. Rachev, N.G. Basmanova.

The work is implemented under the framework of the project "Creating a text corpus for children in their native languages (Evenki, Nenets, Nganasan, Dolgan) as a way to preserve the unique cultural heritage of the indigenous peoples of the Krasnoyarsk Krai (Territory)" supported by the Krasnoyarsk Regional Science Foundation.

DOI: 10.17516/1997-1370-2016-9-9-2044-2059.

Research area: theory and history of culture.

The artists have always paid attention to decoration of children's literature. Illustrating collections of fairy tales, poems, primers and other printed publications, the target audience of which were children, has been main occupation of such outstanding masters as I.Ia. Bilibin, A.N. Benois, M.V. Dobuzhinskii, V.G. Suteev, V.M. Konashevich and many others.

Introducing children with their native culture, with other cultures, is carried out, among other things, through a book, in the structure of which illustration plays a significant role. Such authors as M.A. Alueva (2010) and O.E. Nechaeva (2008) note that in many respects the child's attention is attracted by the visual image. Illustration gives children a better understanding of a text that they either read by themselves or listen to. Such authors as G.A. Kuliupina, Ia.V. Zhukova, V.V. Tiukhtina (2014) pay

(C) Siberian Federal University. All rights reserved

* Corresponding author E-mail address: masha_kolesnik@mail.ru 
attention to illustration possibilities in the children's book structure.

Thus, a book, a mandatory element of which is illustration and other elements of its decoration, becomes a kind of a conductor contributing to learning a native or foreign culture, its adequate perception and formation of the aesthetic and philosophical conceptions of a person from the very childhood. That is why it is so important to analyze how the books for children of the Indigenous peoples in the North, Siberia and the Far East are illustrated, and define the basic techniques and tools chosen by the artists in the context of the problem of transmission of national colors and features of the world-view of different ethnic groups living in the studied region.

An important factor in determining the relevance of the chosen topic for the study is the fact that the works of art, including book illustration, can effectively contribute to the design of different identities: regional, ethnic, national and ethnocultural. Research on this subject was conducted by A.V. Kistova (2011, 2013), N.M. Libakova (2012, 2015), E.A. Sertakova (2015), N.A. Seredkina (2013, 2014), N.N. Pimenova (2013), M.A. Kolesnik (2015).

Such Soviet and Russian illustrators as E.K. Evenbakh, N.G. Basmanova, E.M. Rachev, V.V. Egorov, L. Egorova (collections of fairy tales of the peoples of the North and Siberia), E.S. Gorokhovskii (Dolgan fairy tales), E.A. Bel'mach, K.V. Ovchinnikov (Chukchi, Nanai, Nenets fairy tales), G. Spirin, Kh.A. Avrutis (Khanty fairy tales), L.Iu. Popova (collection of Dolgan fairy tales edited by V.P. Bettu, for a collection of poems by Ogdo Aksenova) have created illustrations for children's literature of the indigenous peoples of the North and Siberia. Among the artists working on decoration of collections of fairy tales of the peoples of the Far East and Siberia, we can single out G.D. Pavlishin and I.G. Pavlishina. T.Ia. Koroleva (Nivkh fairy tales) specializes in patterns created in the tradition of arts and crafts of the Nivkh people living in the territory of Sakhalin.

Modern illustrators of the Dolgan folklore are E. Porotov and Iu. Porotova who work in the art of computer graphics and live in the Krasnoyarsk Territory.

It should be noted that on the Internet there is not much information on all the listed authors, and it is very hard to find monographs or articles in periodicals. However, the credibility of such artists as G.D. Pavlishin, N.G. Basmanova and E.M. Rachev in the field of book illustration is undeniable, as evidenced by the number and frequency of republication of books with their works. Particular attention should also be paid to the artists working with book publishers of the Krasnoyarsk Territory and residing there, since their activities are not covered in the scientific literature. Meanwhile, the Territory is home to a large number of the indigenous peoples of the North. Throughout the twentieth century huge work on collecting materials on the folklore of these peoples has been carried out, which has contributed to the emergence of a number of collections for children with colorful illustrations.

\section{Research Methodology}

The purpose of this article is to systematize the material and write a review on how, when and who decorated children's publications related to the folklore (fairy tales, riddles, poems, etc.) and adaptation of fairy tales of the indigenous peoples of the North, Siberia and the Far East. It is also important to determine what characteristics of visual images presented in printed publications, what features of people, lifestyle, art and ideas about the world the artists visualize, and what ideas on the ethnic groups children will get when reading these books.

In the context of the problem we used an analytical and descriptive method, because to this 
day no work was carried out in the description and systematization of children's literature of the indigenous peoples of the North on the basis of its specific decoration.

Furthermore, the study was based on the principles of philosophical-art-historical analysis developed by V.I. Zhukovsii and N.P. Koptseva (2004, 2011).

Moreover, the structure of the current study included elements of a semiotic analysis, especially in the part where the analysis of book decoration is carried out using the national ornament elements.

\section{Literature review}

The research literature on illustrating children's books is quite extensive. It can be divided into several blocks.

One of these blocks is literature on how a book illustration affects the perception of a child in the process of reading. M.V. Mikhailova and M.A. Milovzorova (2015) write about the social and cultural role of illustrations in children's books, identify a number of important functions performed by illustration: cognitive, communicative, integrative and humanizing functions, and also note a huge role of illustrations in the process of socialization of children, in the development of their creative abilities and aesthetic sense.

Let us distinguish the article by E.V. Iuzhakova (2015), which focuses on history of the Leningrad school of children's book illustrations and describes the 1920's in the development of the national art of illustration.

Such authors as V.V. Korostelina (2013), O.V. Pozdniakova (2013), S.D. Borodina, Iu.G. Emanova, M.K. Iao (2013), O.E. Nechaeva (2008) write on the current problems faced by the illustrators of children's books.

O.V. Pozdniakova (2013) also raises an issue on the relevance of the typographic practice for children in the age of digital technology, introduces with the diverse methods and techniques of illustrating modern publications, and comes to the conclusion that a printed book contributes to the establishment of communication links of a child and strengthening of family relationships.

S.D. Borodina, Iu.G. Emanova, M.K. Iao (2013) in their article introduce a concept of "relevant illustration", point out that it should be mandatory for children's books, and describe the achievements of the Soviet school of illustration in this area, since the artists worked in accordance with the recommendations offered by experts in the field of psychology. A similar perspective is also considered by A.A. Pavlov (2015) by the example of the creative work of the artist and art historian V.N. Liakhov.

The article by O.E. Nechaeva (2008) presents an analysis of major problems associated with the use of a folklore material in contemporary typography. It also provides a list of authors who have ever covered in their writings the main issues related to the decoration of books. The author draws attention to the need for thoughtful and diligent work of an artist-illustrator with primary sources, especially when working on books for children so there would not be a stereotypical misconception about culture of a certain people. O.E. Nechaeva writes about the main possible ways, in which the artists can interpret the folk tradition: stylization, direct quotation, creating a new artistic image. In her opinion, the artist should not ignore the fonts, patterns and the peculiarities of the color score.

The literature on creativity of individual illustrators should be allocated in a separate, though small, unit.

E.Z. Gankina (1963) writes about illustrators of children's books working from the end of the $19^{\text {th }}$ century till the 60 's of the $20^{\text {th }}$ century, covers the main stages and their features in the development of Soviet art of book graphics. 
The article by O.B. Vakhromeev (2016) is devoted to the artist-illustrator Evgeniia K. Evenbakh (1889-1981), and pays special attention to her contribution to the development of culture of the peoples of the North. A monograph by V.S. Matafonov (1988) is also devoted to her creative methods.

\section{Course of the study and its results}

Since there is quite a large number of publications of children's literature of the peoples of the North, the course of the study appears to be constructed as follows: at first, we should describe the major milestones in illustrating children's literature that correspond to the stages of data collection and study of these peoples from the end of the $19^{\text {th }}$ century to this day; then proceed with the analysis of the main methods, by which the artists present an ethnic group in the book decoration, and features of the ethnos representation in different regions (in West and East Siberia and the Far East); and, finally, it seems necessary to carry out the philosophical, art-historical and semiotic analysis of several illustrations made by the most outstanding artists in order to identify the image of various ethnic groups.

The earliest of the found illustrations in children's books on the interested subject include works by the artist Evgeniia K. Evenbakh (18891981), a representative of the Leningrad art school. These are the illustrations from the period of the 1930 's of the $20^{\text {th }}$ century, when E.K. Evenbakh worked on the design of primers for the Kets, the Nanai and the Khanty, and also created a series of illustrations for fairy tales of the Nanai. It is interesting that theartistparticipatedinexpeditions to the peoples living in the Far East and knew about life and living conditions. E.K. Evenbakh was one of the rare artists who sought her artistic objectives by a thorough study of culture of the peoples, sought to convey plausible life details aiming, in this case, not only at children, but also at the adult audience. It should also be noted that E.K. Evenbakh worked in a period when in the country a systematic work on the creation and production of print literature in the indigenous languages was carried out, therefore, the artists collaborated with the scientists and participated in the research themselves.

In the same period, Natalia G. Basmanova (1906-2000) has begun to work together with E.K. Evenbakh in Leningrad and, by an example of her works from to the 1960's we can see the basic principles that guided the illustrators in the mid-twentieth century in decorating children's literature of the indigenous peoples. The book "Cuckoo" consists of two folk tales: the Nanai "Ayoga" and the Nenets "Cuckoo". A muted colour palette based on the contrast of a palette of gray and yellow-green hues that the illustrator uses in decoration of the whole book conveys not only the severity and intensity of the plot of moralizing tales with a tragic ending, but also aims to visualize the atmosphere of harsh and cold nature of the North. Influence of the work with E.K. Evenbakh in the prewar period, a thorough study of culture and life of the peoples of the North are evident in the illustrations for these two little tales. In the drawings of the main characters - four children of a woman who turned into a cuckoo and Ayoga, N.G. Basmanova focuses on the details of clothing and introduces a pattern, which relates specifically to the Nenets and Nanai cultures. However, the reader's attention is focused on the emotional mood that is transmitted by illustrations.

A contemporary of the two above-mentioned artists is Evgenii M. Rachev (1906-1997) who in the 1970's engaged himself in illustrating the collection of tales of the North "Kutkha the Raven" (1974), in the 1980's - the book "A snowbunting" (1980) and "The Bear and the Hare Tevasi” (1984). E.M. Rachev mostly illustrated 


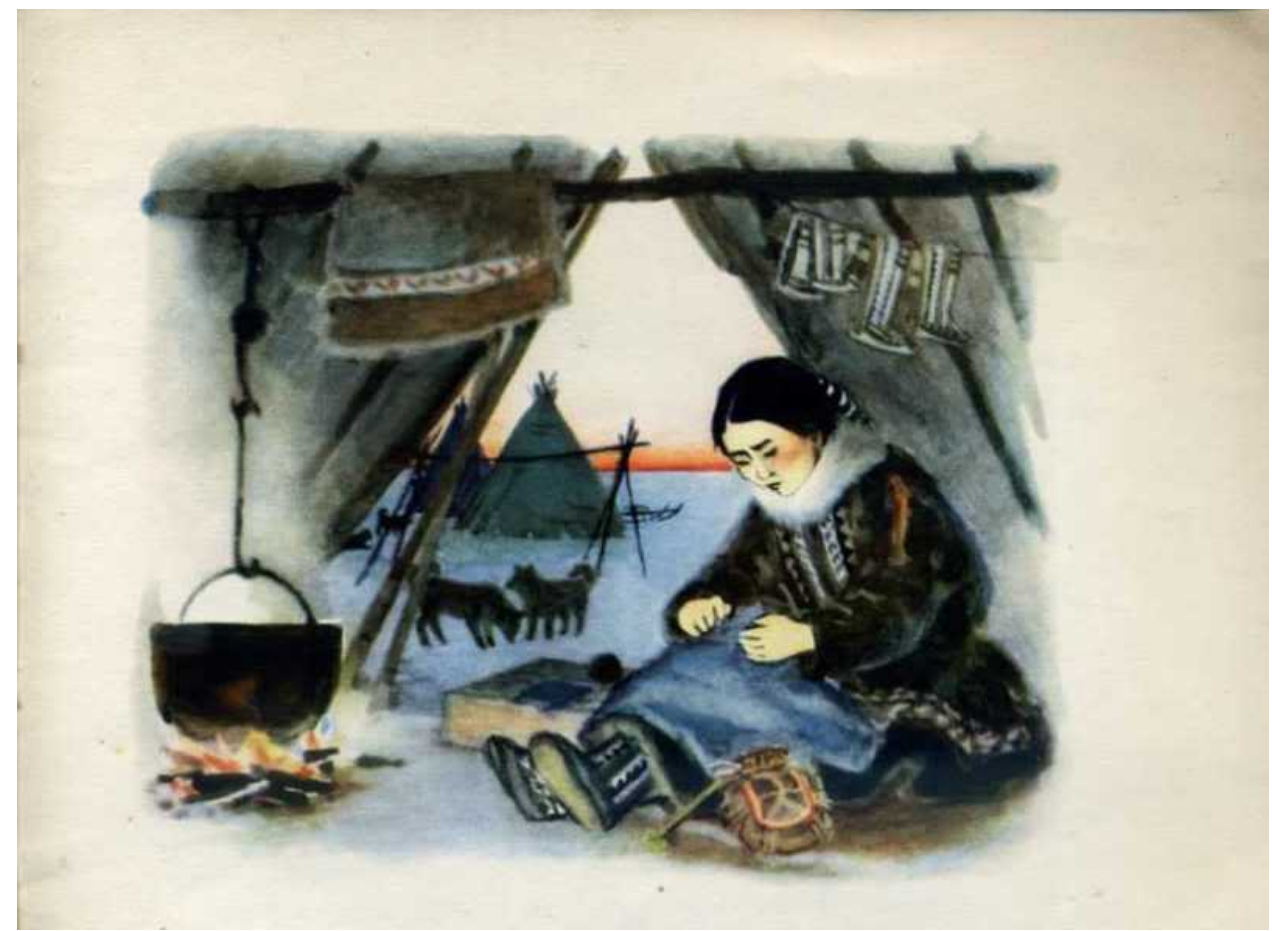

N.G. Basmanova. Illustration of the Nenets folk tale "Cuckoo". Cuckoo. Tales of the North (1962)

tales about animals, being, first of all, an animal artist. The North coloration in his illustrations to this collection is conveyed due to the fact that animals are dressed as people: in parks, bakari, pimy, live in chums and ride their sleds. Here, like in the graphics of N.G. Basmanova, a colour range is in cold tones messaging features of the weather and climate conditions, in which the tales take place. National characteristics of the peoples living on the territory of the North and Siberia are represented only through drawings of clothing of fairy-tale characters that is specifically tailored and decorated with fur and ornaments. In addition, the artist uses small ornamental insertions at the end of tales stylized as a traditional ornament of the indigenous peoples of the North.

V.V. Egorov and L.A. Egorova in many respects similarly decorate the collection "Fairy tales of the peoples of the North" with the only difference that, like for many children's books of the 1990's, the colour range becomes brighter and more eye-catching. In the drawings the artists endow animals with anthropomorphic features portraying them dressed up in clothes, actively use decorative inserts on every page of the book. All these patterns are purely decorative design of the book, and they are placed without any compliance with the texts. For example, the ornament adorning the cover page that precedes the block of tales of the Dolgans, is not characteristic of the traditional ornament used in clothing and adornments of this ethnic group. In this collection the illustrators concentrate primarily on the image of animals, which allows the reader to form an idea of the diverse fauna of Siberia, the North and the Far East. Human images are rare, but they also embody the supremacy of the animal world: for example, on the only illustration with the main human characters, beautiful Ayoga is shown at the moment of becoming a bird, and a few pictures of people placed in the ending of the tales are generalized in a typical image of a Northerner clothed in fur with coloured ornaments. On the pages of the book we see a hunter with a dog, a 


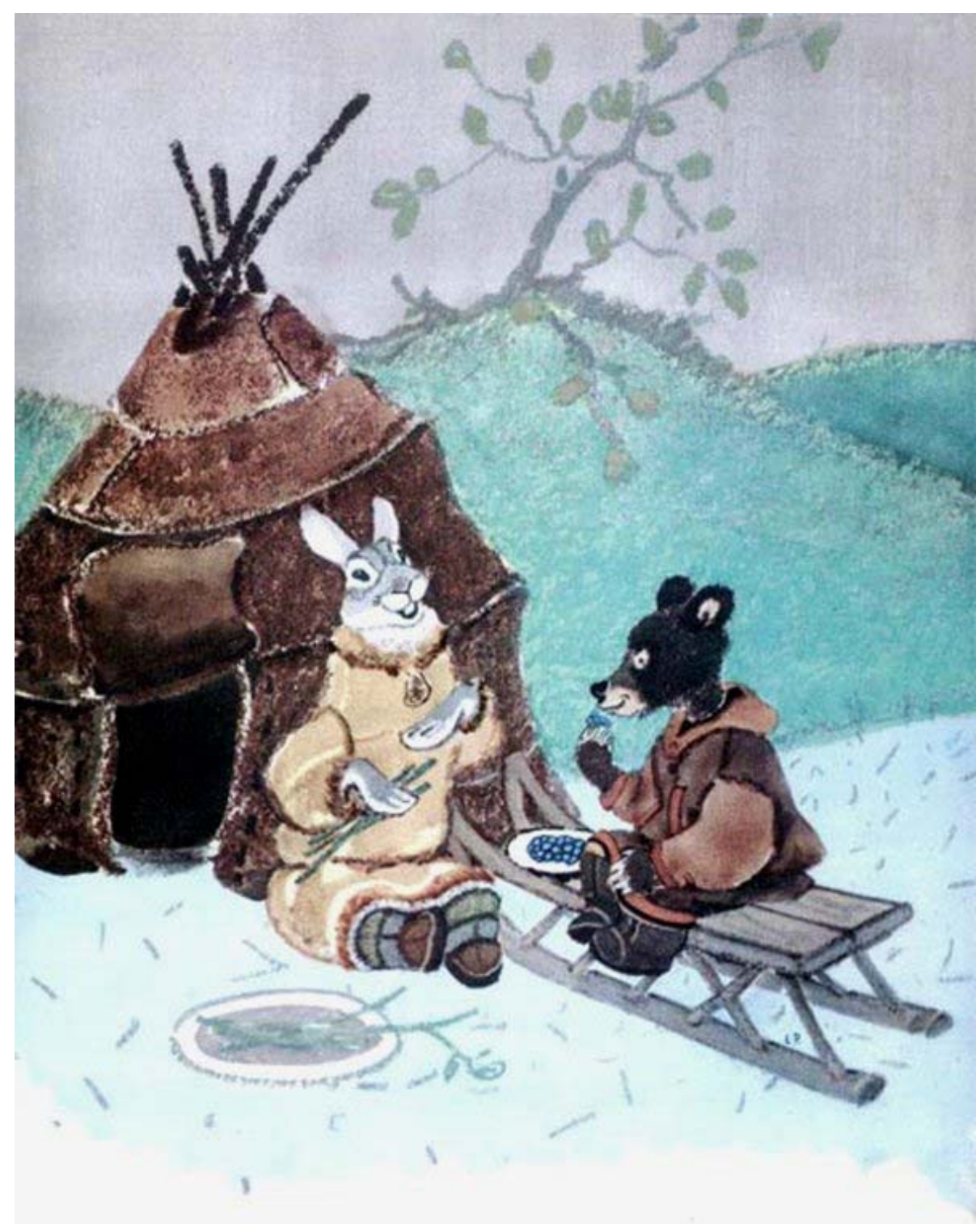

E.M. Rachev. Illustration to the tale "I want to roam - I do not want to roam". "Kutkha the Raven" (1974)

young couple in fur clothes, a shaman in a bird mask, more looking like a beast than a man, and finally, a deer rider. It should be noted that the objects of everyday life and human dwellings are shown in the illustrations very sparingly. The artists pay the greatest attention to the image of the natural world denoting the typical features of the northern landscapes: snow, northern lights, ice, pine and birch forests, mountains of a fantastic shape.
A stylization technique is quite popular for many publications of tales of the North and Siberia. For example, the artist Kh.A. Avrutis makes illustrations looking like images on a carpet, which is emphasized by uneven edges of the frame. Some images resemble fur mosaic, which is typical of masters developing traditional crafts of the indigenous peoples of the North.

An example of successful combination of vivid images and interesting details that form 


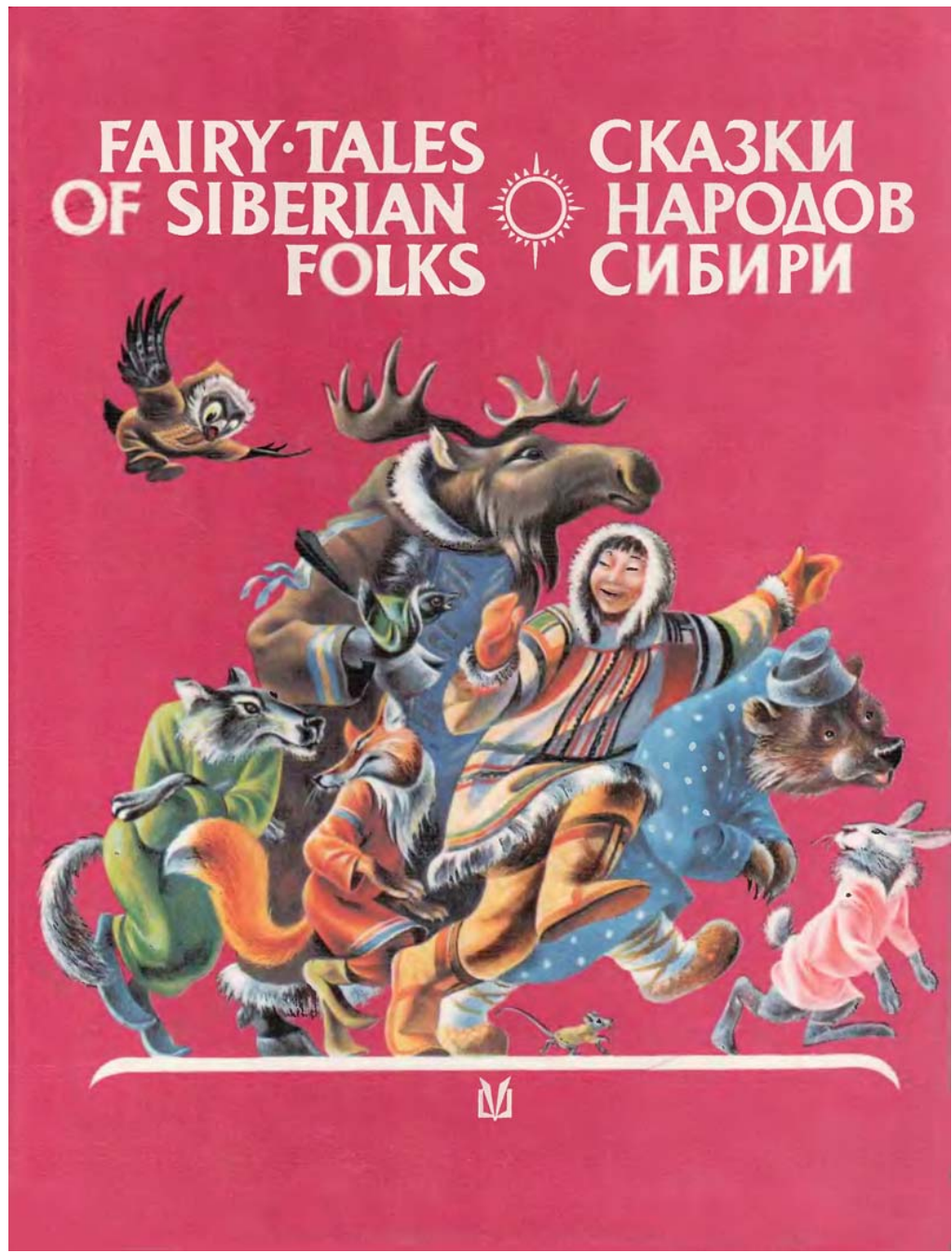

V.V. Egorov, L.A. Egorova. Cover of the collection "Fairy Tales of Siberian Folks" (1992)

an idea of culture of the peoples inhabiting the northern territory of the Krasnoyarsk Territory is the collection "Legends and tales of the polar night". A group of authors worked on the decoration of this book. The emphasis is made on the representation of a traditional costume of ethnoses whose tales were included in the collection. Diverse cultures are combined due to the artistic solution by an interesting and elegant way: the images of ribbons embroidered with a traditional ornament serve as a guiding thread that gradually extends through all the pages of the book. The ribbons decorated by an ornament are rendered as a kind of a framework for the cover of the book, which itself carries information about the world order principles that are universal to all cultures. The illustration on the cover is divided into three areas symbolizing the underworld, the world inhabited by humans and the celestial space. It also determines the specificity of the space, in which a human exists, and establishes the ethnic and natural coloration. The spaces, between which he exists, are a contrast between light and darkness. Among the illustrations there are many large images of the tales characters presented in such a way that you can see the details of the embroidery on clothes, which helps to form a picture of the peoples of the 


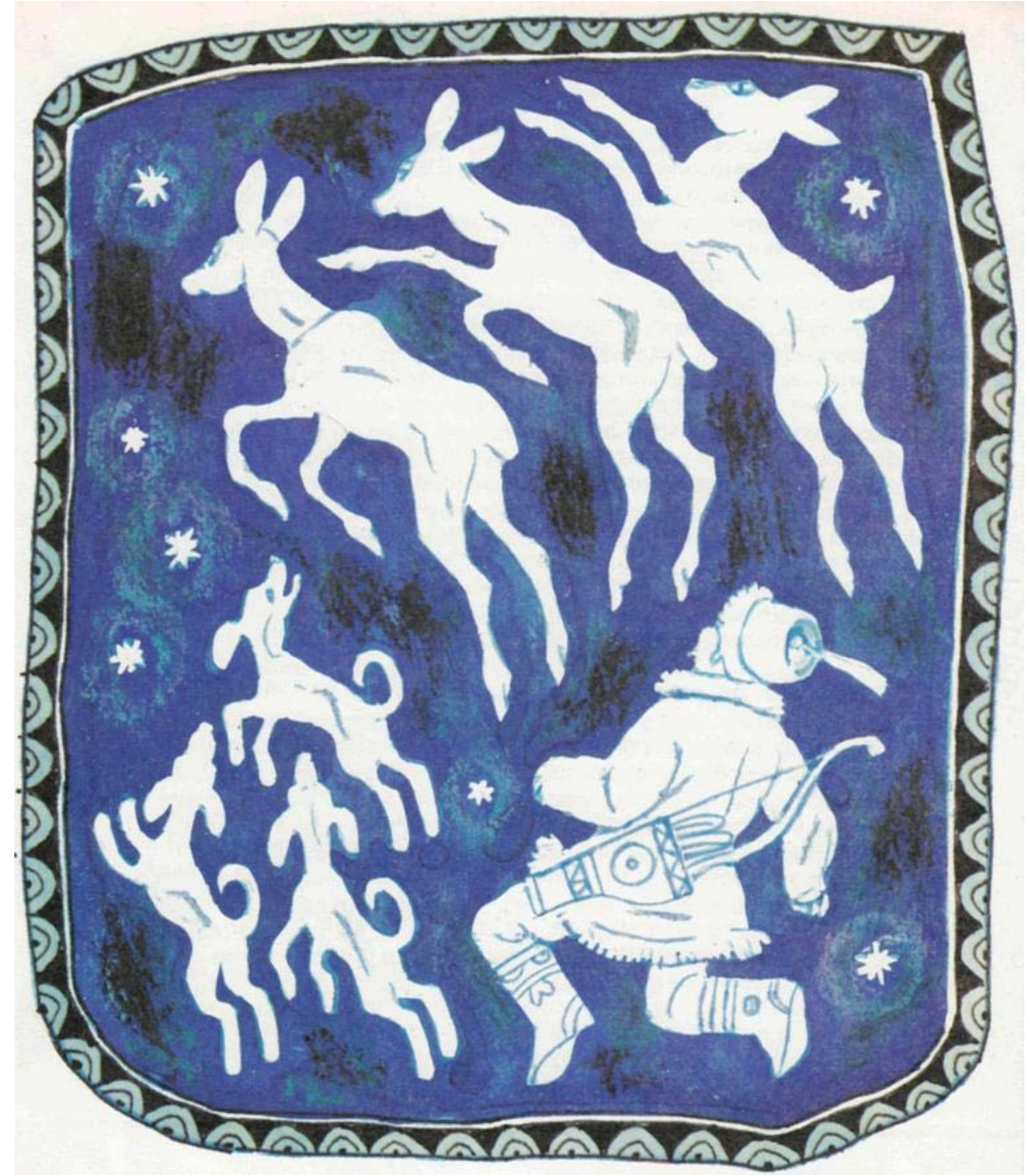

Kh.A. Avrutis. Illustration to the fairy tale "The Three Elks". "Children of the Beast Maany" (1988)

North as the carriers of a rich tradition of arts and crafts, which undoubtedly contributes to creating a positive and interesting image of the Northern ethnic groups. The book is rich with images of people in traditional clothing (men, women, hunters, shamans), scenes from the traditional life of peoples, such as tailoring with elements of fur mosaic, ritual dance of a shaman, hunter riding on sleds. Costumes of the Nganasans, for example, in general terms, are shown correctly, consisting of a cross-linked black and light-coloured deerskin with stitched inserts of a denticulate ornament built on the contrast of black and white colours, which corresponds with the traditional look of a Nganasan. The same can be said about the illustrations for tales of the Dolgans and Ents.
Quite expensive and richly illustrated publications of collections of fairy tales have come out in the 2010's. For example, "Tales of the Amur" illustrated by the artist from Khabarovsk G.D. Pavlishin. In this collection, we can highlight a series of images dedicated to the image of children and the world of children. Thus, through these pictures a conversation is carried out in a language that is understood by any child, but with certain details pointing to the ethnic and cultural identity of the depicted character.

Three illustrations made by G.D. Pavlishin have been selected for the analysis: "Little Elga" (p. 175), "How Beldy stopped fighting" (p. 251), "Brave Azmun" (p. 5). 


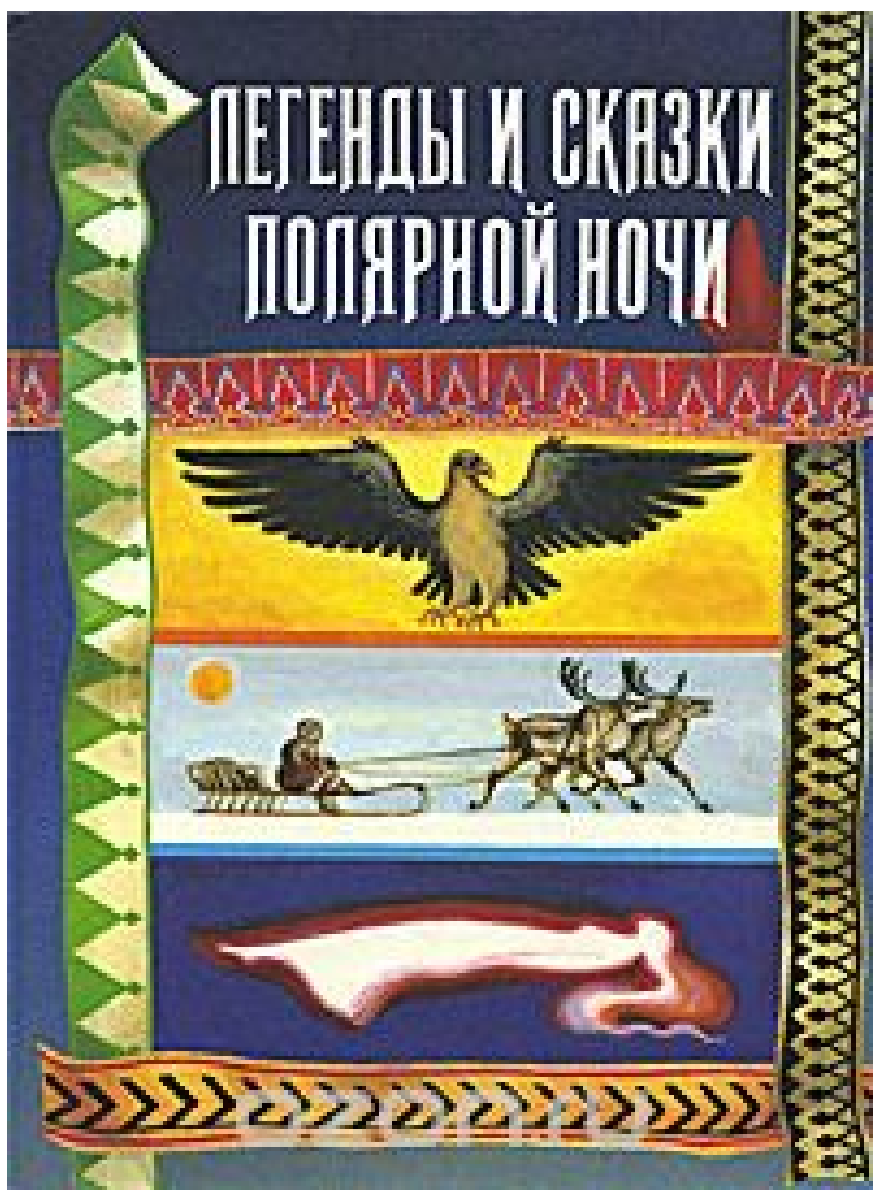

Cover of the collection "Legends and tales of the polar night" (1994)

Head ornament to the Nanai tale "Little Elga". Against the background of a patterned carpet there is a sitting girl dressed in a national costume. She holds a bow in her hands and there are many objects around her. In the foreground there are wooden toys: sleds, dogs and a deer. Behind the girls we can see a cradle, a round wooden plate with patterns and embroidered pieces of cloth, a tumbler and a beater for skin preparation. The objects are arranged in such a way that she is keen by viewing toys symbolizing a man's world associated with hunting, while the items related to women's activities serve as a backdrop and do not fall into the focus area of the heroine.

The carpet that serves as a background is decorated by the traditional Nanai ornament consisting of helical motifs. The same applies to the objects shown on the left from the girl's figure.

In this illustration the artist presents not only the basic development of the plot, in which the heroine is drawn to the activities of her hunter father, but also the two types of items that characterize male and female occupations, as well as children's toys that are traditional in the upbringing of boys in the Nanai culture.

The next illustration is based on the story of the Nanai tale "How Beldy stopped fighting". Here, similar to the previous illustration, all the characters are pictured against the background of a patterned carpet. At first glance, we see an ordinary domestic scene from the life of the Nanai women and children. But what if we look 


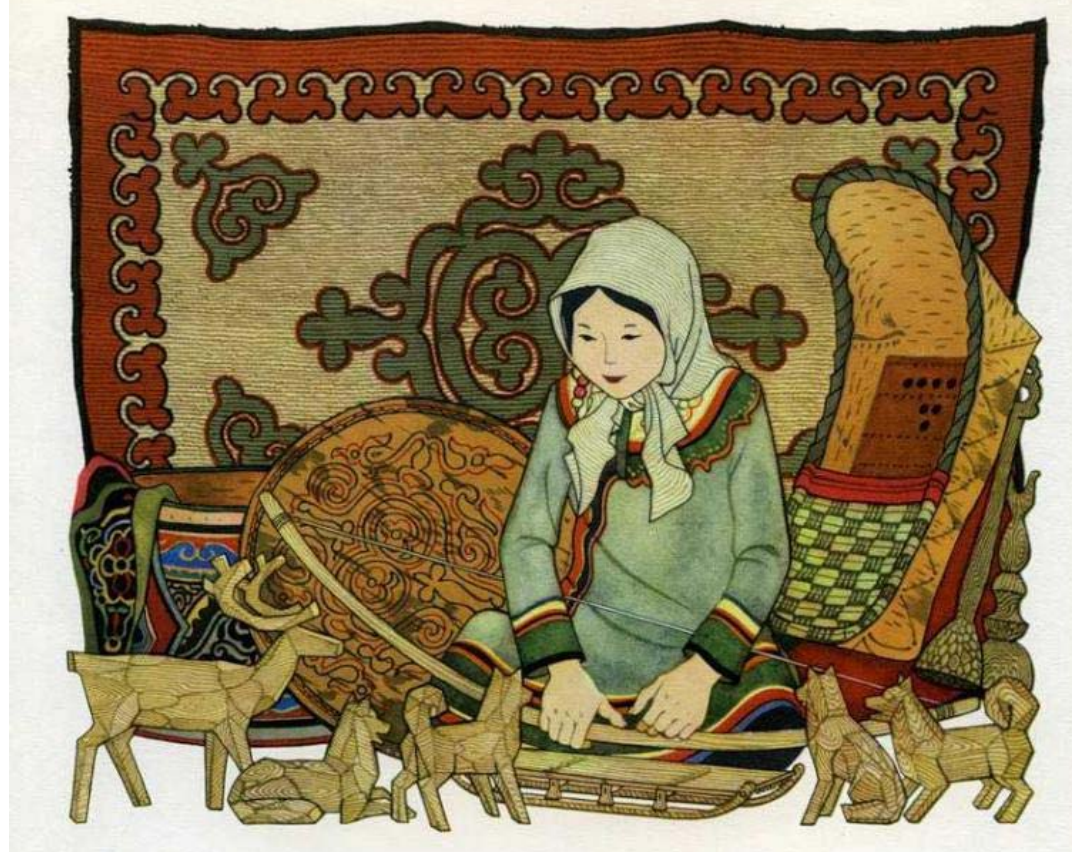

G.D. Pavlishin. Illustration to the Nanai tale "Little Elga”. Nagishkin D.D “Tales of the Amur” (2016)

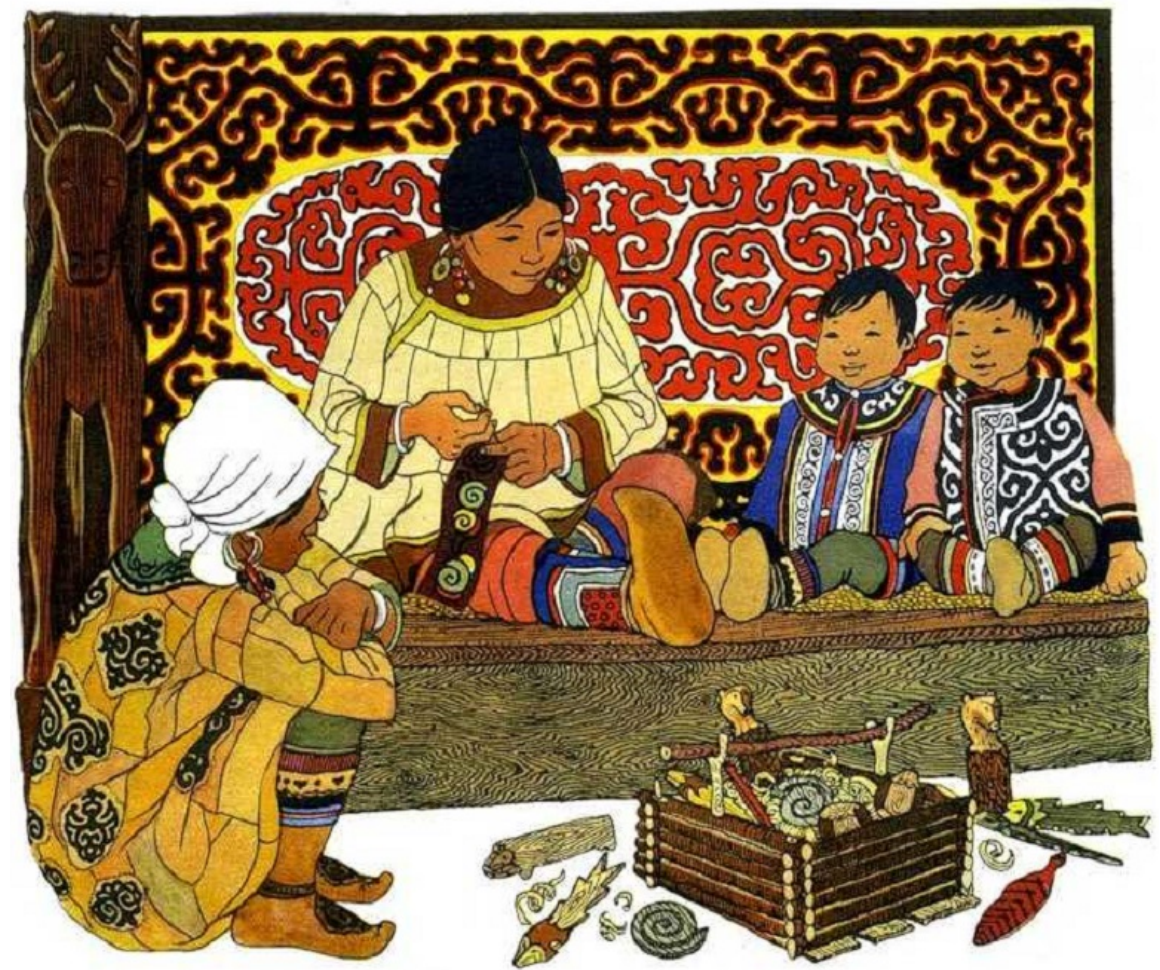

G.D. Pavlishin. Illustration to the fairy tale "How Beldy stopped fighting". Nagishkin D.D. "Tales of the Amur" (2016). 


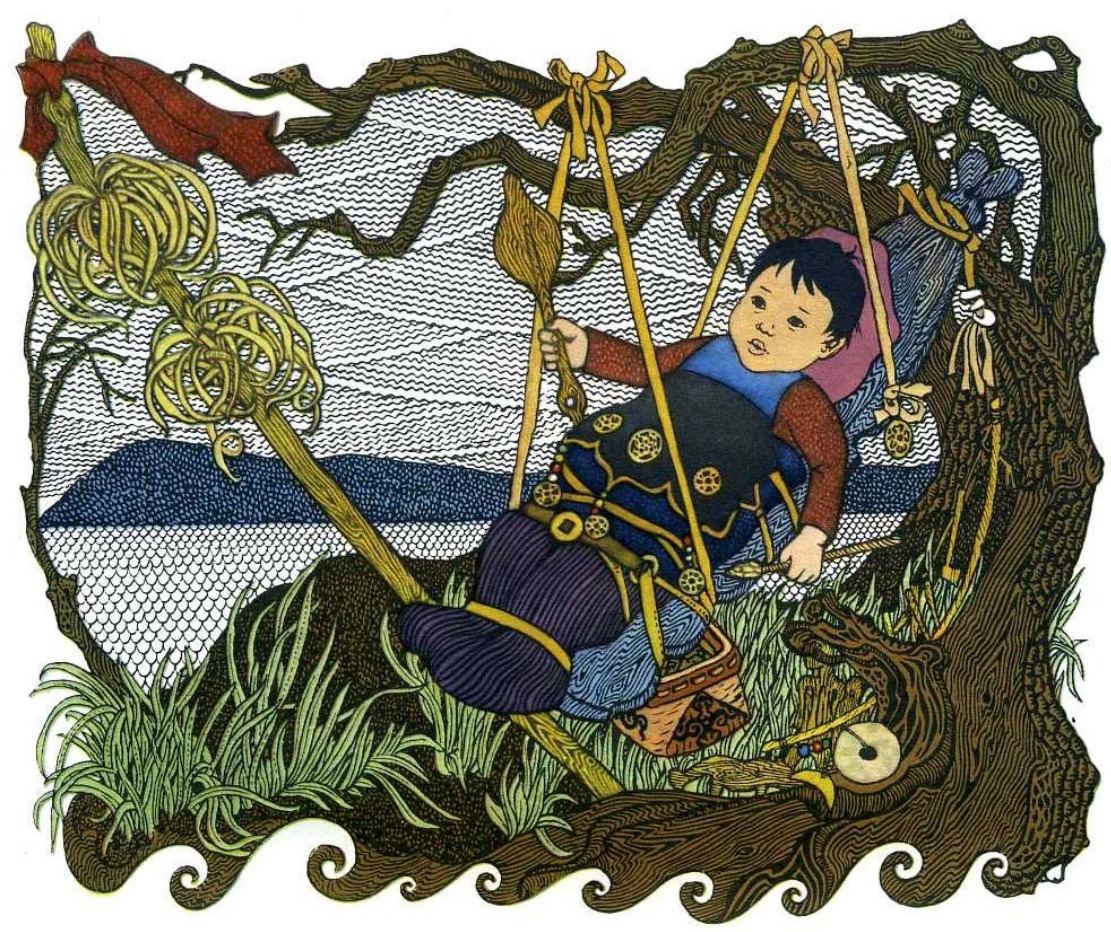

G.D. Pavlishin. Illustration to the fairy tale "Brave Azmun". Nagishkin D.D. "Tales of the Amur" (2016)

more closely? A woman with embroidery and two twin boys are sitting on a plank-bed. A woman in a robe embroidered with patterns is sitting on the floor from the left. And before all of them, on the floor, there is a box with a lot of things in and around it: shells and animal figurines cut from sticks, as well as two wooden figures with dog heads. On the one hand, the viewer is watching an ordinary scene of conversations between the hostess and guests. But the items placed in the center of the composition are not toys as it may seem at first glance. If we address to the tale, it becomes clear that it is children depicted in the picture that are the main characters. Because they are twins, which is a very good sign among the Nanai people, they do fortune-telling. And this very moment was captured by the artist. Among the items lying on the floor and in the box there are two identical figures with dog heads. Women used these figures to smooth out the seams, and their children played with them. But also these figures were used in shamanic divination rites, in particular, with their help people learned about future children. Thus, in this illustration, the artist introduces us not just to the plot of the tale, but also to some cultural characteristics of the ethnic group and its traditions.

And finally, an illustration to the tale "Brave Azmun". It demonstrates the moment of the first appearance of the tale's hero, namely, where the hunters found him: he was tied to a pole on a floating khavykh-island holding a spear in one hand and a paddle in the other. In this case, the artist introduces a natural space as a background, only in a decorative manner. The figure of a child presented in the natural space demonstrates one of the principles of children's upbringing in the culture of the peoples of the Far East: a child from an early age was engaged in the activities of adults, and in case of the tale's hero it is fishing.

Thus, G.D. Pavlishin creates a series of drawings, through which not only children, but even adult readers can get acquainted with the 
peculiarities of cultures of the indigenous peoples inhabiting the territory of the Far East.

\section{Conclusions}

The result of the study is a short overview description of how the decoration of children's literature of the indigenous peoples of the North, Siberia and the Far East has been developed. It was determined that the active work on illustrating children's books has been conducted since the 1930's of the $20^{\text {th }}$ century based on a serious approach to the study of the culture of small nations. Postwar publications are more colourful and attractive for children's audience, over time the artists shift the emphasis towards more decorative design solutions of books in general. Starting from the 1980's there are more and more publications, decoration of which includes stylization on traditional patterns and natural environment of the indigenous peoples of the North, and a bias towards the fantastic interpretation of images. Beginning from the 2010's, when readers start approach the choice of books more legibly and critically, the level of complexity of illustration increases, and the authors, as well as the book publishers just like in the early twentieth century strive for accuracy and study ethnographic materials.

In addition, we made conclusions on how the most successful editions of collections of tales presented ethnoses, their culture, worldview and traditions. First of all, it is people with rich culture, experts in the field of arts and crafts. Based on how the characters of tales are presented in illustrations we can say that the indigenous peoples inhabiting the northern areas are able to survive in harsh environments due to the ability to find common ground with animals and nature, to see the world animated.

Also, based on the analysis we can talk about the techniques that artists often use in illustrating literature of the indigenous peoples:

- inclusion of patterns in pictures and the overall decoration of the book (either stylized in a common style or, which is observed in the publications of the last decade, according to the tradition of the people whose literature is illustrated);

- illustrating specific natural and climatic zone: the ground is covered with snow, ice, twilight sky, polar light, etc.;

- illustrating the diverse animal world, and often animals are endowed with anthropomorphic features: make human actions, dressed in clothes, live in a human home, interact with objects of the human everyday life;

- eliminating a generalized character of a human living in the territory of the North, Siberia and the Far East: dark-haired, with slanting eyes, strong and powerful, engaged in hunting, fishing if a character is a man, and cooking and sewing if the main hero of illustration is a woman or a girl. All people certainly wear clothes richly decorated with ribbons and embroidery, made of fur or leather. A human is always shown in conjunction with the forces of nature, as well as in connection with otherworldly powers (images of shamans, fantastic creatures and situations).

\section{References}

Alueva, M.A. (2010). Spetsifika illiustrirovaniia detskoi khudozhestvennoi knigi v kontekste ee integratsii s detskoi literaturoi i pedagogikoi detskogo chteniia [Specificity of illustrating children's books in the context of its integration with children's literature and pedagogy of children's reading], In Istoricheskaia i sotsial'no-obrazovatel'naia mysl' [Historical and social-educational thought], 2, 64-66.

Borodina, S.D., Emanova, Iu.G., Iao, M.K. (2013). Illiustratsiia kak sredstvo dostizheniia relevantnosti teksta: mezhotraslevoi podkhod [Illustration as a means to achieve the relevance 
of the text: interdisciplinary approach], In philologiia i kul'tura [Philology and Culture], 4, 260-266.

Deti zveria Maany [Children of the beast Maany] (1988). Skazki narodov Sibiri o zhivotnykh [Children of the beast Maany. Tales of the Peoples of Siberia about animals]. Novosibirsk, Novosibirskoe knizhnoe izdatel'stvo.

Gankina, E.Z. (1963). Russkie khudozhniki detskoi knigi [Russian artists of children's books]. Moscow.

Il'beikina, M.I. (2014). Osobennosti vizual'no-antropologicheskikh issledovanii indigennykh narodov [Features of the visual-anthropological studies of the indigenous peoples], In Sovremennye problemy nauki i obrazovaniia [Modern problems of science and education], 4, 594.

Iuzhakova, E.V.(2015). Mezhdu miriskusnikami i konstruktivistami: tvorchestvo V.V. Vladimirova i Leningradskaia detskaia knizhnaia illiustratsiia v 1920-e gg. [Between the world artists and the constructivists: creative work of V.V. Vladimirov and the Leningrad children's book illustration in the 1920's, In the Izvestiia Ural'skogo federal'nogo universiteta [Proceedings of the Ural Federal University]. Series 2: Humanities, 145 (4), 47-56.

Kile, A.S. (2004). Iskusstvo nanaitsev: vyshivka, ornament. Traditsii i novatsii [Art of the Nanai: embroidery, ornament. Traditions and innovations]. Khabarovsk.

Kistova, A.V. (2013). Konstruirovanie etnokul'turnoi i obshchenatsional'noi identichnostei na osnove etnograficheskogo podkhoda v sotsial'noi filosofii [Construction of ethno-cultural and national identities based on the ethnographic approach in social philosophy]. PhD thesis. Krasnoyarsk.

Kistova, A.V. (2013). Stanovlenie filosofii kul'tury kak metodologicheskoi osnovy gumanitarnogo znaniia [Formation of the culture philosophy as a methodological basis of the Humanities knowledge], In Sovremennye problemy nauki i obrazovaniia [Modern problems of science and education], 1, 401.

Kolesnik, M.A. (2015). Konstruirovanie russkoi kul'turnoi identichnosti: kontseptual'nyi $i$ metodologicheskii podkhody [Construction of the Russian cultural identity: conceptual and methodological approaches]. PhD thesis in cultural studies. Krasnoyarsk.

Kolesnik, M.A. (2014) Obzor izucheniia fol'klora korennykh narodov Severa [Review of the study of folklore of the indigenous peoples of the North]. Litera, 3, 9 - 11.

Koptseva, N.P., Libakova, N.M. (2012). Formirovanie rossiiskoi kul'turnoi identichnosti v obrazovatel'noi deiatel'nosti sovremennogo universiteta posredstvom izucheniia istorii russkogo izobrazitel'nogo iskusstva [Formation of the Russian cultural identity in the educational activities of the modern university through the study of history of the Russian art], In Pedagogika iskusstva [Pedagogy of art], 4, 7-29.

Koptseva, N.P. (2014). K voprosu o gosudarstvennoi politiki v oblasti sokhraneniia iazykov korennykh malocheslennykh narodov Severa [On the question of the state policy in the field of preservation of languages of the indigenous peoples of the North], In Arktika i Sever [The Arctic and the North], 16, 34-40.

Koptseva, N.P., Bralkova, A.V., Gerasimova, A.A., Govorukhina, Iu.A. et al. (2015). Novaia artkritika na beregakh Eniseia [New art critic on the banks of the Yenisei]. Krasnoyarsk, Siberian Federal University.

Koptseva, N.P., Nevol'ko, N.N., Reznikova, K.V. (2013). Formirovanie etnokul'turnoi identichnosti $\mathrm{v}$ sovremennoi Rossii s pomoshch'iu proizvedenii natsional'nogo iskusstva (na primere evenkiiskogo 
eposa i dekorativno-prikladnogo iskusstva) [Formation of the ethno-cultural identity in modern Russia with the help of works of the national art (by the example of the Evenk epic and arts and crafts), In Pedagogika iskusstva [Pedagogy of Arts], 1, 1-15.

Koptseva, N.P., Seredkina, N.N. (2013). Konstruirovanie pozitivnoi etnicheskoi identichnosti $v$ polikul'turnoi sisteme [Construction of a positive ethnic identity in a multicultural system]. Krasnoyarsk, Siberian Federal University.

Koptseva, N.P., Sertakova, E.A., Il’beikina, M.I., Zamaraeva, Iu.S., Libakova, N.M., Bakhova, N.A., Luzan, V.S., Reznikova, K.V., Kistova, A.V., Pimenova, N.N., Nevol'ko, N.N. (2011). Kul'tura korennykh i malocheslennykh narodov Severa $v$ usloviiakh global'nykh transformatsii [Culture of the indigenous peoples of the North in the conditions of global transformations]. St. Petersburg, 2011. 174.

Korostelina, V.V. (2013). Aktual'nye tendentsii v khudozhestvennom oformlenii serii detskikh knig [Recent trends in the decoration of series of children's books], In Vestnik Moskovskogo gosudarstvennogo universiteta pechati [Bulletin of the Moscow State University of Printing Arts], 7, 24-28.

Kukushka. Severnye skazki [Cuckoo. Tales of the North]. (1962). Leningrad. State Publishing House of children's literature of the Ministry of Education of the RSFSR.

Legendy i skazki poliarnoi nochi [Legends and tales of the polar night]. (1994). Dudinka, Taimyrpressfoto-2.

Libakova, N.M. (2015). Formirovanie pozitivnoi etnicheskoi identichnosti indigennykh narodov posredstvom dekorativno-prikladnogo iskusstva (rez'ba po kosti) [Creating a positive ethnic identity of the indigenous peoples through the arts and crafts (bone carving)], In Sovremennye problemy nauki i obrazovaniia [Modern problems of science and education], 1, 1889.

Libakova, N.M., Sertakova, E.A. (2014). Kul'turologicheskoe issledovanie korennykh malochislennykh narodov Severa Krasnoiarskogo kraia: rezul'taty ekspertnogo interv'iu [Cultural Study of the Indigenous Peoples of the North of the Krasnoyarsk Territory: results of the expert interview], In Sovremennye problemy nauki i obrazovaniia [Modern problems of science and education], 4, 598.

Matafonov, V.S. (1988). Evgeniia Konstantinovna Evenbakh [Evgeniia K. Evenbakh]. Leningrad.

Mikhailova, M.V., Milovzorova, M.A. (2015).vSotsiokul'turnyi status illiustratsii v sovremennoi detskoi knige Rossii: tendentsii i problemnye polia [Sociocultural illustrations status in a contemporary children's book in Russia: trends and problem areas], In Istoriia i kul'turologiia [History and Culture Studies], 6, 101.

Nagishkin, D.D. (2016). Amurskie skazki [Tales of the Amur]. Moscow, Saint Petersburg.

Nechaeva, O.E. (2008). Interpretatsiia narodnoi traditsii v sovremennom knozhnom dizaine [Interpretation of the folk tradition in the modern book design], In Vestnik Tomskogo gosudarstvennogo universiteta. Filologiiia [Bulletin of Tomsk State University. Philology], 3 (4), 102-117.

Pavlova, A.A. (2015). Problemy stilevoi sviazi illiustratsii i proizvedeniia khudozhestvennoi literatury u V.N. Liakhova [Problems of the style connection of illustration and works of literature by V.N. Liakhov], In Vestnik Moskovskogo gosudarstvennogo universiteta pechati [Bulletin of the Moscow State University of Printing Arts], 2, 406-427.

Pozdniakova, O.V. (2013). Dizain sovremennoi detskoi knigi kak iskusstvo [Design of the modern children's book as art], In Vestnik Tomskogo gosudarstvennogo universiteta. Filologiiia [Bulletin of Tomsk State University], 2 (117) 206-2011. 
Razumovskaia, V.A. (2012). Izometriia v lingvistike i perevodovedenii: rasshirenie kategorial'noi paradigmy [Isomerism in linguistics and translation studies: extension of the categorical paradigm], In Iazyk i kul'tura [Language and Culture], 4 (20), 49-61.

Razumovskaia, V.A. (2015). Kognitivnye osobennosti avtorskogo perevoda poezii [Cognitive features of the author's translation of poetry], In Kognitivnye issledovaniia iazyka [Cognitive language studies], 22, 521-523.

Reznikova, K.V. (2014). K voprosu ib utochnenii poniatii "etnos" i "etnichnost" [On the issue of clarifying the concepts of "ethnos" and "ethnicity", In Sotsiodinamika [Sociodynamics], 12, 90-102. DOI: 10.7256/2409-7144.2014.12.13913. URL: http://e-notabene.ru/pr/article_13913.html

Reznikova, K.V. (2016). K voprosu ob epicheskom kul'turnom nasledii korennykh malochislennykh narodov Krasnoiarskogo kraia [On the question of the epic cultural heritage of the indigenous peoples of the Krasnoyarsk Territory]. Litera, 2, 20-34. DOI: 10.7256/2409-8698.2016.2.18917. URL: http://enotabene.ru/fil/article_18917.html

Reznikova, K.V. (2012). Sotsial'noe konstruirovanie obshchenatsional'noi identichnosti v Rossiiskoi Federatsii [Social construction of national identity in the Russian Federation]. Abstract of $\mathrm{PhD}$ thesis. Krasnoyarsk.

Savvinov, A.I. (2010). Etnokul'turnye osobennosti v ornamental'nykh traditsiiakh dolgan [Ethnocultural features in the ornamental traditions of the Dolgans], In Vestnik Dal'nevostochnogo otdeleniia Rossiiskoi akademii nauk [Bulletin of the Far Eastern Branch of the Russian Academy of Sciences], 2, 55-65.

Sem, T.Iu. (2002). Tipy shamanskikh ritualov nanaitsev kak forma perekhodnykh obriadov [Types of the Nanai shamanic rituals as a form of transition rites]. Studia Culturae, 4, 83-97.

Seredkina, N.N. (2014). K voprosu o metodologicheskikh printsipakh kul'turno-semioticheskogo podkhoda v izuchenii iskusstva indigennykh narodov Severa, Sibiri i Dal'nego Vostoka [On the question of methodological principles of the cultural and semiotic approach to the study of the art of the indigenous peoples of the North, Siberia and the Far East], In Chelovek i kul'tura [Human and Culture], 2, 127-146. DOI: 10.7256/2306-1618.2014.2.11320. URL: http://www.e-notabene.ru/ca/ article_11320.html

Shaburova, O.A. (2013). Natsional'nye aktsenty v vospitanii nanaiskikh detei [National emphases in education of the Nanai children], In Psikhologiia i pedagogika: metodika i problem prakticheskogo primeneniia [Psychology and Pedagogy: methodology and problems of practical application], 34, 83-88.

Sitnikova, A.A. (2014). Khudozhestvennaia interpretatsiia obraza zhizni na Severe v proizvedeniiakh Rokuella Kenta [Artistic interpretation of lifestyle in the North in the works by Rockwell Kent], In Sovremennye problemy nauki i obrazovaniia [Modern problems of science and education], 4, 593.

Smoliak, A.V. (1991). Shaman: lichnost', funktsii, mirovozzrenie [Shaman: personality, functions, worldview]. Moscow.

Vakhromeeva, O.B. (2016). Biografiia bestuzhevki. Tvorcheskii put' khudozhnitsy E.K. Evenbakh (1889-1981). [Biography of bestuzhevka. Creative methods of the artist E.K. Evenbakh (1889-1981)], In aktual'nye problem gumanitarnykh i estestvennykh nauk [Actual problems of the humanities and natural sciences], 1. 
Zamaraeva, Iu.S. (2015). Global'nye transformatsii, kotorye prerezhivaiut indigennye narody Severa [Global transformations experienced by the indigenous peoples of the North], In Sovremennye problemy nauki i obrazovaniia [Modern problems of science and education], 1-1, 1882.

Zhukova, Ia.V., Kuliupina, G.A., Tiukhtina, V.V. (2014). Detskaia kniga i illiustratsiia: grani soprikosnovemiia [Children's book and illustration: the verge of connection], In Kul'tura i obrazovanie [Culture and Education], 8 URL: http://vestnik-rzi.ru/2014/08/2318.

Zhukovskii, V.I. (2011). Teoriia izobrazitel'nogo iskusstva [Theory of the fine arts]. St. Petersburg.

Zhukovskii, V.I., Koptseva, N.P. (2004). Propozitsii teorii izobrazitel'nogo iskusstva [Propositions of the theory of the fine arts]. Krasnoyarsk.

\title{
Художественное оформление
}

произведений детской литературы

коренных малочисленных народов Севера,

Сибири и Дальнего Востока

\author{
М.А. Колесник \\ Сибирский федеральный университет \\ Россия, 660041, Красноярск, пр. Свободный, 79
}

В статье рассматриваются основные принципь художественного оформления детской литературы коренных малочисленных народов Севера, Сибири и Дальнего Востока, которые использованы художниками-иллюстраторами. Представлен анализ нескольких иллюстраций по сказкам народов Севера, проведен анализ оформления сборников сказок с иелью определения того, какой образ того или иного этноса они формируют. Кратко охарактеризовано творчество таких мастеров детской иллюстрации, как Е.К. Эвенбах, Н.Г. Басманова, Г.Д. Павлишин, E.M. Рачёв.

Ключевые слова: детская литература, долганы, искусство иллюстрации, искусство народов Севера, книжная графика, коренные малочисленные народы, сказки народов Севера, нанайцы, ненцы, Е.К. Эвенбах, Г.Д. Павлишин, Е.М. Рачёв, Н.Г. Басманова.

Работа выполнена в связи с проектом «Создание корпуса текстов для детей на родных языках (эвенкийский, ненецкий, нганасанский, долганский) как способ сохранения уникального культурного наследия коренных малочисленных народов Красноярского края», поддержанным Красноярским краевым фондом науки.

Научная специальность: 24.00.01 - теория и история культуры. 